\title{
IMPLEMENTASI PRINSIP PRODUKSI EKONOMI ISLAM PADA MEBEL IRA BERSAUDARA KOTA BENGKULU
}

\author{
Martina Khusnul Khotimah \\ Pascasarjana Fakultas Ilmu Agama Islam (FIAI) Universitas Islam Indonesia (UII) Yogyakarta \\ Email: martinakhusnulkhotimah473@gmail.com
}

\begin{abstract}
The Ministry of Forestry and industry stated that from 2016 to 2018 the growth of furniture industry tended to decrease from $10 \%$ to $6 \%$. This research is a qualitative research to analyze the application of the principles of Islamic economic production to the Iraqi Brothers Furniture in the City of Bengkulu. The principle of Islamic economic production to be applied in the production process to minimize production activities that cause losses. Humans who are too in love with the world are one thing that makes humans act in accordance with rules or ethics, so that the rules of values and norms on the principle of production have a very important position in the act of control so as not to cause harm to others.The results of this research are that the Iraqi Furniture Minister has not been maximal in applying the principles of Islamic economic production. Then the level of awareness is needed by introspecting whether the production principle used is in accordance with Islamic teachings.

Keywords: monotheism, justice, humanity, virtue, and responsibility
\end{abstract}

Abstrak: Kementerian kehutanan dan industri menyatakan bahwa dari tahun 2016 hingga tahun 2018 pertumbuhan industri mebel cenderung mengalami penurunan dari $10 \%$ menjadi $6 \%$.Penelitian ini adalah penelitian kualitatif untuk menganalisis penerapan prinsip-prinsip produksi ekonomi Islam pada mebel Ira Bersaudara di Kota Bengkulu. Prinsip produksi ekonomi Islam untuk diterapkan dalam proses produksi untuk meminimalkan kegiatan produksi yang menyebabkan kerugian. Manusia yang terlalu cinta terhadap dunia adalah satu hal yang membuat manusia bertindak tidak sesuai dengan aturan atau etika, sehingga aturan nilai dan norma pada prinsip produksi memiliki posisi yang sangat penting dalam tindakan kontrol agar tidak menimbulkan bahaya bagi orang lain. Hasil penelitian ini adalah mebel Ira Bersaudara belum maksimal dalam menerapkan prinsip produksi ekonomi Islam. Maka diperlunya tingkat kesadaran dengan cara mengintropeksi apakah prinsip produksi yangdigunakan sudah sesuai dengan ajaran Islam.

Kata Kunci: Tauhid, keadilan, kemanusiaan, kebajikan, dan tanggung jawab

\section{A. PENDAHULUAN}

Kegiatan produksi adalah kegiatan manusia untuk memenuhi kebutuhan hidupnya terutama konsumen. Jadi produsen muslim disini sebagai khalifah dan ibadah kepada Allah SWT, karena kegiatan tersebut harus dilandasi oleh nilai dan prinsip yang terdapat dalam Alquran dan hadis. ${ }^{1}$ Penerapan prinsip produksi ekonomi Islam hendaknya memberikan tanggung jawab kewajiban yang seimbang pada kelestarian dan kesetaraan manusia. Rasulullah SAW sangat menghargai harga yang adil yang terbentuk di pasar dan nilai-

\footnotetext{
${ }^{1}$ Didin Hafiduddin, Islam Aplikatif, (Jakarta: Gema Insani, 2003), hlm. 28
}

nilai moralitas yang meliputi kejujuran, keadilan dan keterbukaan sangat diperlukan dan menjadi tanggung jawab bagi setiap produsen.

Sistem ekonomi kapitalis telah membuat kesenjangan yang begitu radikal di antara manusia, di mana hampir $20 \%$ penduduk dunia menikmati $80 \%$ hasil kekayaan yang ada di bumi. Di beberapa negara makmur, orang menikmati hidup berkecukupan dan berkelebihan. Sementara di banyak belahan dunia, terdengar pula jerit kelaparan dan kesakitan. $^{2}$

\footnotetext{
${ }^{2}$ Akhmad Mujahidin, Aktifitas Produksi Dalam
} Perspektif Ekonomi Islam, Jurnal Dosen Ekonomi 
Tabel 1.1

\section{Pertumbuhan Industri Mebel \\ Berdasarkan Persentase \\ Tahun 2016-2018}

\begin{tabular}{|c|c|}
\hline TAHUN & PERSENTASE \\
\hline 2016 & $10 \%$ \\
\hline 2017 & $5 \%$ \\
\hline 2018 & $9 \%$ \\
\hline
\end{tabular}

Sumber: Data Sekunder Dari Himpunan Industri Mebel Dan Kerajinan Indonesia (HIMKI) 2018

Perkembangan industri mebel yang meningkat tiap tahunnya. Pada tahun 2016 yang dinyatakan Kementerian Perindustrian (Kemenperin) bagian Industri Hasil Hutan dan Perkebunan meningkat $10 \%$. $^{3}$ Sedangkan pada tahun 2017, HIMKI (Himpunan Industri Mebel dan Kerajinan Indonesia) mencatat nilai ekspor mebel mengalami penurunan ekspor mebel sekitar 5\%. ${ }^{4}$ Sementara pada tahun 2018 menargetkan akan meningkat menjadi $16 \%$ dikarenakan indonesia memiliki sebanyak $80 \%$ bahan baku untuk industri mebel dan kerajinan. Saat ini, hanya bergantung pada bagaimana mengelola bahan baku tersebut menjadi barang yang berkualitas dan berdaya saing tinggi. ${ }^{5}$ Akan tetapi pada

Islam Fakultas Syari'ah Dan Ilmu Hukum UIN Sultan Syarif Qasim, Riau. Vol. 3, No. 2, Maret 2009, hlm. 77

${ }^{3}$ Ramon Patrick Karamoy dkk, Implementasi Sistem Produksi Pada Industri Kecil Menengah (Studi Kasus Pada: Industri Kecil Menengah "Ikm" Di Desa Touliang Oki), Jurnal Berkala Ilmiah Efisiensi, Manado: Volume 16 No. 02 Tahun 2016, hlm. 561

${ }^{4}$ Annisa Sulistyo Rini, Industri Mebel Nasional Ditargetkan Tumbuh $16 \%$ Tahun Ini, https://ekonomi.bisnis.com/read/20180105/257/723682/ industri-m 05 Januari 2018 17:10 WIB

${ }^{5}$ Kontan.co.id, Himki prediksi ekspor mebel di 2017 tumbuh $6 \%-7 \%$, https://industri.kontan.co.id/news/himki-prediksi- tanggal 26 Agustus 2018 HIMKI mencatatkan bahwa nilai ekspor mebel mengalami kenaikan yaitu $9 \%{ }^{6}$

Menurut Fahrudin Sukarno, dalam artikelnya yang berjudul "Etika Produksi Ekonomi Islam” (2010), menjelaskan konsep produksi Islami yang bertumpu pada urgensi di Indonesia meningkatkan kesejahteraan manusia dalam masyarakat Islam. Kerangka konsep produksi Islam muncul dasar moralitas untuk melaksanakan kegiatan produksi. Dasar moralitas yang dimaksud adalah prinsip produksi ekonomi Islam (tauhid, keadilan, kemanusiaan, kebajikan, kehendak bebas dan tanggung jawab) yang mempengaruhi pertumbuhan ekonomi, keadilan distributif, program pelestarian lingkungan, dan juga sosial perusahaan tanggung jawab. ${ }^{7}$

Menurut Tamamudin, yang penelitiannya berjudul "Perilaku Produksi Industri Batik Kota Pekalongan Menurut Etika Produksi Islam”(2016), menjelaskan bahwa keserakahan manusia dan kecintaan terhadap dunia adalah satu hal yang membuat manusia bertindak tidak sesuai dengan aturan atau etika, sehingga aturan

ekspor-mebel-di-2017-tumbuh-6-7, Rabu, 10 Januari 2018 / 17:35 WIB

${ }^{6}$ Agung Hidayat, HIMKI: Ekspor Mebel dan Kerajinan Kayu masih tumbuh 9\% di semenster I 2018,http://www.google.com/amp/amp.kontan.co.id/ne ws/himki-ekspor-mebel-dan-kerajinan-kayu-masihtumbuh-9-di-semester-i-2018, Minggu 26 Agustus 2018 16:11 WIB

${ }^{7}$ Fahrudin Sukarno, Etika Produksi Ekonomi Islam, Jurnal Ekonomi Islam Al-Infaq, Bogor: Vol. 1 No. 1, September 2010, hlm. 50 
nilai dan norma memiliki posisi yang sangat penting dalam tindakan kontrol agar tidak menimbulkan bahaya bagi orang lain. Perusahaan selalu berusaha mengikuti prinsip keseimbangan dalam semua aspek. Keseimbangan adalah kunci kelangsungan hidup perusahaan. ${ }^{8}$

Mebel Ira Bersaudara menjual produk berupa perabotan rumah tangga yang melayani cash dan credit. Mebel ini dipimpin oleh bapak Mardaus yang didirikan sejak tahun 1982. Mebel ini terdiri dari 5 karyawan bagian pengecatan, 2 orang supir, 1 karyawan perempuan sebagai pramuniaga dan 4 orang tukang yang membuat barang mentah menjadi setengah jadi. Mebel ini sudah bergabung pada perusahaan kredit yang ada di Bengkulu diantaranya PT. Master, PT. Unity, PT. BAMA, PT. Interyasa, dan PT. Adira Furniture. ${ }^{9}$

Mebel Ira Bersaudara Kota Bengkulu yang pelaku produsennya adalah masyarakat agamis.

Adapun permasalahannya yaitu dari pelayanan terhadap konsumen yang tidak ramah dan rasa tanggung jawab yang kurang, keadilan dan kemanusiaan sehingga akan membuat kerugian terhadap volume penjualan produk

\footnotetext{
${ }^{8}$ Tamamudin, Perilaku Produksi Industri Batik Kota Pekalongan Menurut Etika Produksi Islam, Jurnal Hukum Islam, IAIN Pekalongan, Jawa Tengah Indonesia :Vol. 14, No.2, Desember 2016, hlm. 112113

${ }^{9}$ Mardaus, wawancara pada tanggal 30 Oktober 2018
}

dan konsumen merasa tidak puas. Jadi perlunya penerapan prinsip produksi ekonomi Islam agar tercapainya maslahah baik produsen maupun konsumen.

Fahrudin Sukarno menyatakan bahwa akan ada dampak dasar moralitas prinsip produksi terhadap pertumbuhan ekonomi yang meningkatkan kesejahteraan manusia khususnya di Indonesia. Penerapan prinsip produksi pada mebel Ira bersaudara sesuai dengan ajaran Islam dan apakah ada peningkatan penjualan jika mebel ini menerapkan prinsip produksi ekonomi Islam.

\section{B. PRODUKSI DALAM EKONOMI} ISLAM

Produksi secara ekonomi konvensional adalah kegiatan yang tidak hanya berorientasi pada barang dan jasa tetapi suatu proses mengubah kombinasi input menjadi output, yang menitiberatkan pada pencapaian maksimum keuntungan. ${ }^{10}$

Sedangkan produksi secara Islam berbeda dengan defenisi produksi secara konvensional. Produksi secara Islam menekankan pada pengoptimalan efisiensi dan pengoptimalan keuntungan. Jelaslah bahwa produksi secara Islam tidak hanya mencari keuntungan semata melainkan ibadah oriented sehingga apapun barang yang diproduksi maka seseorang produsen

${ }^{10}$ Adiwarman Karim, Ekonomi Mikro Islam, (Jakarta: RajaGrafindo Persada, 2007), hlm. 101 
Islam akan menekankan etika di dalam produksi. ${ }^{11}$

Jadi kegiatan produksi dalam perspektif Islam berkaitan dengan manusia dan eksistensinya dalam aktivitas ekonomi, meskipun definisi tersebut memberikan penekanan yang berbeda-beda. Secara garis besar masing-masing definisi menyebutkan bahwa setiap kepentingan manusia yang sesuai dengan aturan dan prinsip syariat harus menjadi target dari suatu kegiatan produksi. Produksi merupakan proses mencari, mengalokasikan dan mengolah sumber daya menjadi output dalam rangka meningkatkan dan memberi maslahah bagi manusia. $^{12}$

Beberapa prinsip produksi dalam ekonomi Islam yang berkaitan dengan maqashid al-syariah antara lain:

1. Kegiatan produksi harus dilandasi dengan nilai-nilai Islam dan sesuai dengan maqashid al- syariah. Tidak memproduksi barang atau jasa yang bertentangan dengan pengjagaan terhadap agama, jiwa, akal keturunan dan harta.

2. Prioritas produksi sesuai dengan prioritas kebutuhan, yaitu dharuriyat, hajiyat dan tahsiniyat.

\footnotetext{
${ }^{11}$ Ibid., hlm. 251

${ }^{12}$ M Nur Rianto Al Arif, Pengantar Ekonomi Syariah, (Bandung: CV Pustaka Setia, 2015), hlm. 211212.
}

3. Kegiatan produksi harus memerhatikan aspek keadilan, sosial, zakat, sedekah, infak, dan wakaf.

4. Mengelola sumber daya alam secara optimal, tidak boros, berlebihan dan merusak lingkungan.

5. Distribusi keuntungan yang adil antara pemilik dan pengelola, manajemen dan buruh. $^{13}$

Ajaran Islam ditemukan sejumlah ayat AlQur'an baik secara tersirat maupun tersurat yang menjelaskan pentingnya penerapan prinsip produksi untuk kemaslahatan manusia yaitu:

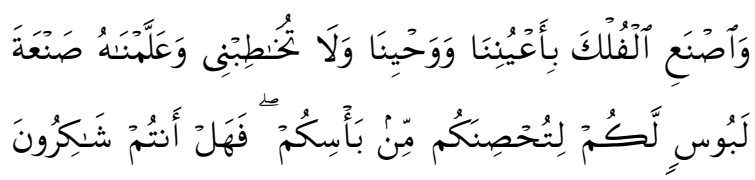

Artinya: "dan telah Kami ajarkan kepada Daud membuat baju besi untuk kamu, guna memelihara kamu dalam peperanganmu; Maka hendaklah kamu bersyukur (kepada Allah).”(QS Al- Anbiyya (21): 80)

Ayat diatas menjelaskan bahwa

Allah mengajarkan Nabi Daud a.s. Cara membuat baju besi. Membuat baju besi merupakan proses produksi. Tujuan membuat baju besi dalam ayat ini sebagai pelindung ketika peperangan terjadi (dipakai dalam rangka berjihad $f i$ sabilillah). ${ }^{14}$ Dengan demikian terdapat prinsip produksi ekonomi Islam yaitu prinsip tauhid. Karena Nabi Daud a.s

\footnotetext{
${ }^{13}$ Ika Yunia Fauzia Dan Abdul Kadir Riyadi,
} Prinsip Ekonomi Islam Perspektif Maqasid Al- Syariah, (Jakarta: Kencana, 2014), hlm. 128

14 Ahmad Mustafa Al- Maragi, Tafsir AlMaragi, (Semarang: Toha Putera, 1992), hlm. 96 
membuat baju besi bukan semata-mata untuk memakainya melainkan untuk beribadah (berperang) dalam menegakan agama Islam.

Umar Ra. Berpendapat bahwa melakukan aktivitas produksi lebih baik daripada mengkhususkan waktu untuk ibadah-ibadah sunnah, dan mengandalkan manusia dalam mencukupi kebutuhannya. Seperti yang diriwayatkan bahwa beliau melihat tiga orang di masjid tekun beribadah dan beliau bertanya"Dari mana kamu makan?" Ia menjawab, "Aku adalah hamba Allah SWT dan mendatangkan kepadaku rizkiku bagaimana Dia menghendaki." Lalu Umar bertanya kepada orang kedua seraya dengan menanyakan hal yang sama. Maka dia memberitahu kepada Umar dengan mengatakan, "Aku memiliki saudara yang mencari kayu di gunung untuk dijual, lalu dia makan sebagian dari hasilnua dan dia datang kepadaku memenuhi kebutuhanku." Maka Umar berkata, "Saudara kamu lebih beribadah daripada kamu." Kemudian umar mendatangi orang yang ketiga dan menanyakan hal yang sama. Ia menjawab pertanyaan Umar, "Manusia melihatku, lalu mereka datang kepadaku dengan sesuatu yang mencukupiku." Maka Umar memukulnya dengan tongkatnya dan berkata kepadanya, "keluarlah kamu ke pasar, atau ucapan yang seperti itu." 15

1. Prinsip-Prinsip Produksi Islam dan implementasinya

a. Prinsip Tauhid

Menurut Chapra, ia memandang ada tiga prinsip dasar Islam, yaitu tawhid, khilafah dan 'adalah (keadilan) sebagai kerangka yang tidak saja membentuk Islamic Worldview, tetapi juga maqasid Asy- Syari'ah (tujuan Islam. ${ }^{16}$ Prinsip tauhid adalah ajaran fundamental Islam. Prinsip ini mengatakan bahwa produsen melangsungkan kegiatannya karena ketundukannya pada Allah SWT dan termotivasi beribadah kepada-Nya. Berdasarkan prinsip ini Allah SWT menetapkan batasan, aturan dan hukum atas aktivitas produksi yang dilakukan manusia, menegaskan kewajiban mereka pada Allah SWT. Implementasi dari prinsip tauhid dalam kegiatan produksi terwujud dari produksi yang dihasilkan berupa produk produk yang halalan toyiban dan terhindar dari unsur ribawi, gharar, maisir atau riswah. ${ }^{17}$

${ }^{15}$ Dr. Jaribah Al- Haritsi, Al-Fiqh Al-Iqtishadi, ahli bahasa H. Asmuni Solihan Zamakhsayari dan Muhammad Ihsan, LC. Fikih Ekonomi Umar bin AlKhathab, Cet. 3 (Jakarta: Khalifa, 2010), hlm. 43

${ }^{16}$ Veithzal Riva'i dan Andi Buchari, Islamic Economics Ekonomi Syariah Bukan Opsi, Tetapi Solusi, ( Jakarta: Bumi Aksara, 2009), hlm. 379

${ }^{17}$ Fahrudin Sukarno, Etika Produksi Perspektif Agama Islam, (Bogor: Al Azhar, 2010), hlm. 44. 
Implementasi prinsip tauhid ini dapat dilakukan melalui:

1) Produsen tidak hanya mencari keuntungan semata melainkan juga memperoleh profit ibadah, memberikan manfaat bagi orang lain, dan mengaktualisasikan kemampuannya sebagai hamba Allah SWT

2) Motivasi beribadah memberikan sebanyak mungkin manfaat kepada konsumen.

3) Memproduksi barang dan jasa yang halal dan baik.

4) Menyusun tata kelola perusahaan yang baik agar menghasilkan pertumbuhan dan kesinambungan usaha secara sehat.

5) Menjalankan mekanisme produksi dengan asas efektif dan efisien, melalui analisis kelayakan usaha, manajemen risiko, analisis bisnis dan lain sebagainya.

6) Membayar zakat, sedekah, dan infak baik oleh produsen maupun karyawan dalam berbagai jenjang.

7) Melaksanakan program CSR dan program kemanusiaan lainnya yang berguna stakeholder perusahaan termasuk masyarakat sekitar.
8) Memperlakukan karyawan dan stakeholder lainnya secara adil dan proporsional. ${ }^{18}$

b. Prinsip Kemanusiaan

Prinsip kemanusiaan, pertama adalah kewajiban untuk menyembah Allah SWT, kedua adanya perbedaan kapasitas dan kemampuan di antara manusia di mana perbedaan itu menjadi ujian untuk meningkatkan kemampuan masyarakat. Berdasarkan prinsip ini, kegiatan produksi bukan semata-mata kegiatan ekonomi, tapi juga bentuk pengabdian manusia pada khalik-Nya serta relasi antara manusia dengan alam. ${ }^{19}$

Implementasi kegiatan produksi pada prinsip ini, dimana semua manusia mempunyai hak untuk mengaktualisasikan kemampuan produktifnya untuk meningkatkan kapasitas kesejahteraannya. ${ }^{20}$ Adapun implementasi pada prinsip ini $\operatorname{adalah}^{21}$ :

1) Memberi kesempatan yang luas bagi setiap manusia untuk

${ }^{18}$ Fahrudin Sukarno, Etika Produksi Perspektif Agama Islam, di edit dalam Dewan Pengurus Nasional Fordeby dan Adesy, Ekonomi Dan Bisnis Islam Seri Konsep dan Aplikasi Ekonomi dan Bisnis Islam, (Jakarta: RajaGrafindo Persada, 2016), hlm. 267

${ }^{19}$ Fahrudin Sukarno, Etika Produksi Perspektif Agama Islam, hlm. 45-46

${ }^{20}$ Fahrudin Sukarno, Etika Produksi Perspektif Agama Islam, di edit dalam Dewan Pengurus Nasional Fordeby dan Adesy..., hlm. 258

${ }^{21}$ Ibid., hlm, 268 
mengaktualisasikan kemampuan ekonominya.

2) Seorang produsen memproduksi barang dan jasa berdasarkan kategori kebutuhan manusia untuk memudahkan kehidupan di dunia.

3) Memaksimalkan keuntungan harus disertai upaya memaksimalkan social return terutama bagi kelompok yang membutuhkan.

4) Larangan memproduksi barang dan jasa yang menimbulkan mudharat, haram dan menghancurkan keluruhan martabat manusia.

5) Menjaga persaudaraan sesama manusia.

6) Prinsip kemanusiaan menjadi tujuan kegiatan produksi yaitu memuliakan harkat dan martabat manusia sebagai hamba Allah SWT.

c. Prinsip Keadilan

Prinsip ini menegaskan bahwa berlaku adil dengan siapa punakan meningkatkan kapasitas produksi dan kualitas hidup manusia. Dengan tujuan memperbesar volume kesejahteraan manusia secara umum. Dalam konsep produksi Islam, bentuk keadilan adalah distributif yang memiliki dua pengertian. Pertama, pihak-pihak yang terlibat mendapatkan porsi kesejahteraan sesuai dengan input yang diberikannya secara proposional. Kedua, hak-hak masyarakat dan konsumen sebagai stakeholder produksi harus dipenuhi produsen. ${ }^{22}$ Implementasi pada prinsip keadilan $\operatorname{adalah}^{23}$

1) Memenuhi hak pekerja sesuai dengan kapasitasnya dengan tetap memerhatikan keluruhan martabat manusia.

2) Membayar zakat, infak, sedekah dan CSR bagi kelompok kurang beruntung.

3) Menerapkan mekanisme bagi hasil (mudharabah dan musyarakah) dalam sistem transaksi permodalan dan pendanaan.

4) Melakukan kegiatan konservasi dan pelestarian sumber daya alam.

5) Merekayasa sektor produksi yang full-employment (padat karya) untuk mengentaskan pengangguran dan kemiskinan.

\section{d. Prinsip Kebajikan}

Prinsip ini menegaskan pemahaman bahwa manusia harus melakukan sebanyak mungkin kebajikan dalam hidupnya. Prinsip ini adalah landasan kegiatan produksi dalam Islam yaitu

\footnotetext{
${ }^{22}$ Ibid., hlm. 259

${ }^{23}$ Ibid., hlm. 269
} 
meningkatkan kualitas hidup manusia secara kolektif. Dalam pemberlakuan prinsip ini, produsen tidak bisa semena-mena mengeksploitasi dan mengeksplorasi sumber daya alam kecuali disertai tindakan pemeliharaan dan pelestarian. ${ }^{24}$

Adapun implementasi pada prinsip ini adalah:

1) Seorang manajer dapat menyusun kebijakan strategis dalam meningkatkan kualitas SDM di perusahaannya melalui kegiatan pelatihan, membuka perpustakaan atau tranformasi ilmu pengetahuan sesuai dengan bidangnya.

2) Produsen mewarnai kegiatan produksinya dengan kebajikan mulai dari pengelolaan modal, proses, serta hasil produksi.

3) Dari sisi proses, penghargaan terhadap kinerja, karyawan, manajemen dan transparan dan rapi, cara mengambil keputusan, strategis mengembangkan usaha, cara menyikapi kompetitor, dan eksporasi sumber daya dilakukan dengan skema efektif dan efisien.

e. Prinsip Kebebasan Dan Tanggung Jawab

Prinsip kebebasan dan tanggung jawab bersifat inheren. Kegiatan produksi mengambil manfaat, mengeksplorasi dan mengelola sumber daya ekonomi disertai larangan merusak dan bertanggung jawab untuk melestarikannya. Hal ini menandakan bahwa prinsip kebebasan dan tanggung jawab bermakna untuk menjadi manusia yang berkualitas maka setiap perbuatan bebas manusia harus mengandung implikasi moral dan psikologis yaitu tanggung jawab kepada diri, masyarakat dan tuhannya.

Adapun implementasi pada prinsip ini adalah:

1) Produsen bebas memiliki harta kekayaan dengan meningkatkan kapasitas produksinya disertai tanggung jawab untuk membayar zakat, infak, serta menjaga kelestarian lingkungan hidup.

2) Produsen bebas mengupayakan pertambahan nilai kekayaannya disertai tanggung jawab untuk mendayagunakan serta menginestasikan hartanya itu pada mekaniseme transaksi yang halal.

3) Produsen bebas mengembangkan bisnisnya disertai dengan kewajiban untuk memerhatikan kesejahteraan karyawan, meningkatkan kemampuannya secara bertahap, dan 
memberdayakan masyarakat sekitar dengan program-program strategis ekonomi.

4) Produsen bebas mengaplikasikan kemampuan bisnisnya disertai tanggung jawab untuk meningkatkan pertumbuhan ekonomi, pemerataan kekayaan, pengentasan kemiskinan serta menyediakan lapangan kerja bagi masyarakat. ${ }^{25}$

\section{METODE PENELITIAN}

\section{Jenis Penelitian}

Penelitian ini adalah penelitian lapangan, dimana masalah yang diajukan didalamnya ditentukan pada masalah operasional. Jenis penelitian ini adalah penelitian kualitatif. Penelitian ini dilakukan bersifat evaluation research, yang menganalisa dan menyajikan fakta secara sistematik sehingga dapat lebih mudah untuk dipahami dan disimpulkan berdasarkan pedoman yang berlaku.

2. Lokasi Penelitian dan Sumber data

Penelitian ini dilakukan pada mebel Ira Bersaudara di kota Bengkulu. Adapun alasannya yaitu karena produsen pada mebel ini adalah produsen muslim yang telah mendirikan mebel ini sejak tahun1982 dan bekerjasama kepada beberapa perusahaan kredit, seperti PT. Interyasa, PT. Adira Furniture, PT.

\footnotetext{
${ }^{25}$ Ibid., hlm, 270
}

Master, PT. BAMA dan PT. Unity serta mebel ini sudah memiliki banyak konsumen dan sudah banyak dikenal oleh masyarakat Bengkulu. Adapun sumber data yang digunakan adalah data primer dan data sekunder.

3. Teknik Pengumpulan Data

Teknik pengumpulan data penelitian ini menggunakan, yaitu wawancara, study kepustakaan, observasi dan dokumentasi. Adapun wawancara dilakukan kepada pimpinan mebel Ira Bersaudara, 2 orang karyawan dan 5 orang konsumen.

Tabel 1.2

\section{Instrumen Penelitian}

\begin{tabular}{|c|c|c|c|c|}
\hline \multirow[t]{2}{*}{ Variabel } & \multirow[t]{2}{*}{ Indikator } & \multicolumn{3}{|c|}{ Informan } \\
\hline & & $\begin{array}{l}\text { konsume } \\
\mathrm{n}\end{array}$ & $\begin{array}{l}\text { Pemili } \\
\mathrm{k} \\
\text { Usaha }\end{array}$ & $\begin{array}{l}\text { karyawa } \\
\text { n }\end{array}$ \\
\hline \multirow{5}{*}{$\begin{array}{c}\text { Prinsip } \\
\text { Produksi } \\
\text { Ekonom } \\
\text { i Islam }\end{array}$} & Tauhid & $\checkmark$ & $\checkmark$ & $\checkmark$ \\
\hline & Adil & $\checkmark$ & $\checkmark$ & $\checkmark$ \\
\hline & $\begin{array}{l}\text { Kehenda } \\
\text { k Bebas }\end{array}$ & $\checkmark$ & $\checkmark$ & $\checkmark$ \\
\hline & $\begin{array}{l}\text { Tanggun } \\
\text { g Jawab }\end{array}$ & $\checkmark$ & $\checkmark$ & $\checkmark$ \\
\hline & $\begin{array}{c}\text { Kebajika } \\
\text { n }\end{array}$ & $\checkmark$ & $\checkmark$ & $\checkmark$ \\
\hline
\end{tabular}

4. Teknik Analisis Data

a. Analisis Kualitatif

Analisis Kualitatif yaitu penganalisisan data sekunder, pertama-tama dilakukan inventaris terhadap norma atau prinsip-prinsip 
produksi Islam pada mebel Ira Bersaudara.

b. Analisis Deskriptif

Analisis Deskriptif meripakan penganalisaan data primer secara mendalam dengan menghubungkan pada data sekunder sehingga diperoleh secara jelas dan terperinci fenomena yang menjadi pokok bahasan tanpa melakukan perhitungan secara deskriptif.

c. Penelitian ini menggunakan triangulasi untuk menguji keabsahan data. Triangulasi sumber merujuk pada upaya untuk mengakses sumbersumber yang lebih bervariasi guna memperoleh data berkenaan dengan persoalan yang sama. Alasan penggunaan triangulasi sumber dikarenakan triangulasi sumber sesuai dengan kebutuhan dari peneliti yang ingin menguji kredibilitas data dengan cara mengecek data yang didapat, kemudian data tersebut dideskripsikan, dikategorikan dan dianalisis hingga tercipta suatu kesimpulan. Triangulasi metode digunakan dalam penelitian ini dengan cara membandingkan hasil wawancara yang telah dilakukan dengan dokumen berupa laporan keuangan usaha, guna memperkuat hasil wawancara yang dilakukan.

\section{HASIL DAN PEMBAHASAN}

\section{Implementasi}

Prinsip-Prinsip

Produksi Pada Mebel Ira Bersaudara

Di Kota Bengkulu Dalam Perspektif Islam

Pada penelitian ini melakukan analisis bagaimana penerapan prinsip produksi ekonomi Islam pada mebel Ira Bersaudara di Kota Bengkulu yang sesuai teori prinsip produksi ekonomi Islam yaitu: tauhid, kemanusiaan, kebajikan, keadilan, dan kehendak bebas serta tanggung jawab.

Keesaan, mebel Ira Bersaudara menerapkan prinsip keesaan tauhid melakukan dalam usaha jual beli. Dalam berbisnis, prinsip tauhid adalah kunci keberhasilan suatu produsen yang berupa ibadah yang senantiasa selalu diawasi oleh Allah SWT dan bertawakal kepadaNya. Mebel Ira Bersaudara menanamkan kejujuran dan tidak melupakan kewajiban sebagai umat Rasululah SAW seperti memberikan waktu untuk istirahat dan sholat kepada karyawan. Selain itu mebel Ira Bersaudara melakukan pencatatan transaksi. Hal ini sangat penting bagi produsen agar terhindar dari kesalahan yang mungkin terjadi, dan mendidik para karyawan agar bersikap jujur serta terhindar dari penipuan dan kekhilafan yang mungkin terjadi. Jika ada pembeli yang lupa terhadap hutangnya, maka produsen bisa 
mengingatkannya dan menunjukkan bukti catatannya agar transaksi jual beli dan hutang piutangnya berjalan dengan lancar. Serta mebel ini sering menjalankan Zakat, Infak, Sedekah (ZIS). Cara memperoleh barang, mebel Ira Bersaudara mengambil kayu langsung dari hutan dengan cara halal tidak dengan melakukan penebangan hutan liar yang mana apabila dilakukan akan menyebabkan banjir dan longsor. Ini dibuktikan dengan adanya surat izin usaha perdagangan (SIUP). ${ }^{26}$ Karena sebagian harta yang dimiliki produsen terdapat milik orang lain.

Kemanusiaan, Prinsip ini menjadi tujuan kegiatan produksi yaitu memuliakan harkat dan martabat manusia sebagai hamba Allah SWT. Mebel Ira Bersaudara selalu menjaga hubungan baik (silahturahmi) kepada karyawan dan konsumen. Mebel ini selalu menepati janji kepada konsumen, terutama jika ada konsumen yang memesan barang kepadanya. Dengan menerapkan sifat tepat janji akan mendatangkan rasa kepercayaan dan kepercayaan merupakan modal utama dan harus dimiliki oleh setiap produsen. Selain itu para karyawan di mebel Ira bersaudara ini selalu ramah dan sopan

\footnotetext{
26 Wawancara Ibu Sumiati sebagai Istri Pimpinan (Mardaus) dan Manajer Mebel Ira
} Bersaudara, 4 Desember 2018 serta murah senyum kepada konsumen. Mereka meyakini dengan sopan dan murah hati terhadap pembeli maka akan banyak yang tertarik dan menghampiri mebel ini, karena si pembeli merasa senang dan dihormati. ${ }^{27}$ Namun tidak semua karyawan disini bersikap seperti itu terkadang karyawan yang kurang ramah dan acuh tak acuh terhadap pembeli bahkan mereka suka menggerutu jika ada pembeli yang sudah tanya-tanya harga namun tidak membeli. ${ }^{28}$

Keadilan, bentuk prinsip ini adalah distributif yang memiliki dua pengertian. Pertama, pihak-pihak yang terlibat mendapatkan porsi kesejahteraan sesuai dengan input yang diberikannya secara proposional. Kedua, hak-hak masyarakat dan konsumen sebagai stakeholder produksi harus dipenuhi produsen. Mebel Ira Bersaudara menerapkan prinsip ini, seperti memberikan upah sesuai kemampuan karyawan dan memberikan fee serta bonus kepada karyawan, ${ }^{29}$

Kebajikan, Prinsip ini menegaskan pemahaman bahwa manusia

27 Wawancara Ibu Sumiati sebagai Istri Pimpinan (Mardaus) dan Manajer Mebel Ira Bersaudara, 4 Desember 2018

28 Wawancara Feri Kurniawan, Sebagai Konsumen, 5 Desember 2018

29 Wawancara Ibu Sumiati sebagai Istri Pimpinan (Mardaus) dan Manajer Mebel Ira Bersaudara, 4 Desember 2018 
harus melakukan sebanyak mungkin kebajikan dalam hidupnya. Prinsip ini adalah landasan kegiatan produksi dalam Islam yaitu meningkatkan kualitas hidup manusia secara kolektif. Mebel ira bersaudara menerapkan prinsip ini, seperti memberikan kebijakan kepada karyawan untuk libur 1 minggu sekali secara bergantian. Apabila terdapat karyawan baru yang tidak sesuai dengan keahlian maka produsen memberikan pelatihan selama 1-2 minggu. Dan sering memberikan berupa reward (penghargaan) kepada karyawan. ${ }^{30}$

Kebebasan dan tanggung jawab, setiap produsen harus bertanggung jawab dan mampu menjaga amanah dari masyarakat maupun konsumen. Kewajiban dan tanggung jawab para pedagang antara lain menyediakan barang kebutuhan masyarakat dengan harga yang wajar, kegunaan yang cukup dan manfaat yang memadai untuk semua kalangan. Mebel Ira Bersaudara menerapkan prinsip ini, seperti selalu bertanggung jawab apabila terdapat komplain dari konsumen. Jika pesanan yang dibuat tidak sesuai dengan apa kehendak konsumen, maka mebel ini segera memperbaikinya dan bertanggung jawab dengan cara memberi garansi

\footnotetext{
30 Wawancara Ibu Sumiati sebagai Istri Pimpinan (Mardaus) dan Manajer Mebel Ira Bersaudara, 4 Desember 2018
}

kepada konsumen jika terjadi kerusakan pada produk yang ditawar.

\section{Volume Penjualan Pada Mebel Ira Bersaudara.}

Prinsip-prinsip produksi yang implementatif terkandung dalam prinsip tauhid, keadilan, kebajikan, kemanusiaan, kebebasan dan tanggung jawab. Implementasi prinsip tersebut akan mempengaruhi tingkat pertumbuhan ekonomi, pemerataan dan keadilan distributif, kelestarian lingkungan serta tanggung jawab sosial produsen.

Mebel Ira Bersaudara sudah menerapkan prinsip produksi ekonomi Islam, namun belum secara maksimal. Akan tetapi, dengan menerapkan prinsip tersebut akan berdampak kepada produsen yaitu meningkatnya volume penjualan walaupun tidak stabil. Dikatakan tidak stabil karena setiap bulannya penghasilan sesuai pendapatan produsen kadang meningkat dan kadang menurun. Hal ini di lihat dari laporan keuangan yang dicatat oleh produsen setiap bulan. Maka diperlukan penerapan manajemen strategi pemasaran syariah untuk meningkatkan penjualan.

\section{E. KESIMPULAN}

Setiap perusahaan sangat diperlukan penerapan prinsip-prinsip produksi ekonomi Islam. Karena produksi Islam bukan semata hanya memperoleh 
kebahagian dunia saja akan tetapi juga akhirat. Manusia sebagai khalifah di muka bumi jadi setiap harta yang dimiliki semua ada haknya oranglain. Pada mebel Ira Bersaudara sudah menerapkan prinsipprinsip produksi ekonomi Islam, namun belum maksimal. Maka hal itu perlu intropeksi diri dan saling mengingatkan antara pihak yang berkepentingan. Dan menerapkan dalam hati bahwa setiap kegiatan produksi senantiasa diawasi oleh Allah SWT.

Menurut teorinya, Implementasi prinsip tersebut akan mempengaruhi tingkat pertumbuhan ekonomi, pemerataan dan keadilan distributif, kelestarian lingkungan serta tanggung jawab sosial produsen. Akan tetapi volume penjualan pada mebel Ira Bersaudara mengalami tidak kestabilan (kadang turun dan kadang meningkat). Maka hal itu perlu untuk menerapkan manajemen strategi pemasaran syariah untuk meningkatkan penjualan.

\section{F. SARAN}

1. Untuk mebel Ira Bersaudara diharapkan karyawan serta pihak-pihak berkepentingan dapat mengingatkan dan menjaga prinsip-prinsip yang sudah sesuai ajaran Islam. karena hal itu akan meningkatkan kualitas karyawan dan melayani konsumen serta meningkatkan kualitas produksi barang-barang. Sehingga kedepannya akan lebih dikenal juga dengan produksi barang-barang yang berkualitas dan banyak pembeli yang membeli produk mebel Ira Bersaudara.

2. Untuk penelitian selanjutnya, diharapkan meneliti etika produsen Islam dan penerapan prinsip-prinsip produksi dalam sistem keuangan dalam segi akuntansi dan penerapan sistem upah karyawan apakah sudah sesuai atau tidak ajaran Islam.

\section{DAFTAR PUSTAKA}

Ekonomi Syariah,Bandung: CV
Pustaka Setia.
Perspektif Agama Islam, Bogor: Al
Azhar.
Perspektif Agama Islam, di edit dalam
Dewan Pengurus Nasional Fordeby dan
Adesy, Ekonomi Dan Bisnis Islam Seri
Konsep dan Aplikasi Ekonomi dan
Bisnis Islam, (Jakarta: RajaGrafindo
Persada, 2016), hlm. 267

Akhmad Mujahidin, 2009, "Aktifitas Produksi Dalam Perspektif Ekonomi Islam”, Jurnal Dosen Ekonomi Islam, Vol. 3, No. 2, Maret 2009, Riau: Fakultas Syari'ah dan Ilmu Hukum UIN Sultan Syarif Qasim

Al- Arif , M. Nur Rianto, 2014, Materi Pokok Ekonomi Islam, Jakarta: Universitas Terbuka.

Al- Haritsi, Dr. Jaribah Al-Fiqh Al- Iqtishadi, 2010, Ahli Bahasa H. Asmuni Solihan Zamakhsayari Dan Muhammad Ihsan, LC. Fikih Ekonomi Umar Bin AlKhathab, Cet. 3, Jakarta: Khalifa.

Al- Maragi, Ahmad Mustafa, 1992, Tafsir AlMaragi, Semarang: Toha Putera 
Annisa Sulistyo Rini, Industri Mebel Nasional Ditargetkan Tumbuh 16\% Tahun Ini, https://ekonomi.bisnis.com/read/20180 105/257/723682/industri-m 05 Januari 2018 17:10 WIB

Aziz, Abdul, 2013, Etika Bisnis Perspektif Islam Implementasi etika Islam untuk dunia Usaha, Bandung: Alfabeta.

Hafiduddin, Didin, 2003, Islam Aplikatif, Jakarta: Gema Insani.

Hidayat, Agung, HIMKI: Ekspor Mebel dan Kerajinan Kayu masih tumbuh 9\% di semenster I 2018, http://www.google.com/amp/amp.kont an.co.id/news/himki-ekspor-mebeldan-kerajinan-kayu-masih-tumbuh-9di-semester-i-2018, Minggu 26 Agustus 2018 16:11 WIB

Ika Yunia Fauzia dan Abdul Kadir Riyadi, 2014, Prinsip Ekonomi Islam Perspektif maqasid Al- Syariah, Jakarta: Kencana.

Kontan.co.id, Himki prediksi ekspor mebel di 2017 tumbuh 6\%-7\%, https://industri.kontan.co.id/news/himk i-prediksi-ekspor-mebel-di-2017tumbuh-6-7, Rabu, 10 Januari 2018 / 17:35 WIB

Karim, Adiwarman. 2007 Ekonomi Mikro Islam, Jakarta: RajaGrafindo Persada.

Nur Rianto \& Euis Amalia 2010, , Teori Mikroekonomi, Jakarta: Kencana.

Nasution,Mustafa Edwin dkk, 2007, Pengenalan Eksklusif Ekonomi Islam, Jakarta: Kencana.

Ramon Patrick Karamoy, Petrus Tumade , Indrie Debbie Palandeng ,2016, "Implementasi Sistem Produksi Pada Industri Kecil Menengah (Studi Kasus Pada: Industri Kecil Menengah "Ikm" Di Desa Touliang Oki)", Jurnal Berkala Ilmiah Efisiensi, Manado: Volume 16 No. 02 Tahun 2016.

Riva'i, Veithzal dan Andi Buchari, 2009, Islamic Economics Ekonomi Syariah
Bukan Opsi, Tetapi Solusi, Jakarta: Bumi Aksara

Samuelson,2004, Ilmu Makro Ekonomi Jakarta: Media Global Edukasi

Sukarno, Fahrudin, 2010, "Etika Produksi Ekonomi Islam", Jurnal Ekonomi Islam Al-Infaq, Bogor: Vol. 1 No. 1, September 2010.

Tamamudin, 2016, "Perilaku Produksi Industri Batik Kota Pekalongan Menurut Etika Produksi Islam”, Jurnal Hukum Islam, IAIN Pekalongan, Jawa Tengah Indonesia :Vol. 14, No.2, Desember 2016

Wawancara, Mardaus sebagai pimpinan, 30 Oktober 2018

Wawancara Ibu Sumiati sebagai Manajer mebel Ira Bersaudara, 4 Desember 2018

Wawancara Feri Kurniawan, Sebagai Konsumen, 5 Desember 2018 